\title{
Rule-Breaking and Meaning-Making in Edward Lear
}

\author{
Diane Ponterotto \\ University of Molise
}

\begin{abstract}
Nonsense seems to break many rules of semantico-syntactic compatibility and somehow managed to construct discourse. This paper discusses the work of Edward Lear, the 19th century English writer and painter in a attempt to identify some of the linguistic and psycholinguistic principles underlying the nonsense text. It claims that nonsense relies on a "fuzzy" image - not meaning, but the suggestion of meaning or a feeling of sense, which results basically from the manipulation of the phonemic and lexemic possibilities of the English language and the exploitation of patterns of redundancy, sustained by a rigid syntactic and metric structure. It also suggests a relation to strategies of child language acquisition which would on the one hand explain the popularity of nonsense and on the other hand support the hypothesis that the origin of the genre is to be sought in the nursery-rhyme tradition of English literature.
\end{abstract}

Many attempts at the interpretation of Edward Lear, the 19th century English painter and nonsense poet, have been biographical. Without the life, we cannot understand how his nonsense works or what it is trying to say, holds Byrom in his study on Lear entitled Nonsense and Wonder, which identifies for these limerick and poems meanings related to characteristics claimed to be part of the poet's life and personality, e. g. epilepsy, bachelorhood, fear of ostracism, sense of self-alienation, intolerance of convention and contemporary social restraints, sense of shame about a latent homosexuality, etc. According to Jackson, "nonsense was the safety-valve of his consciousness responding to most of his approaches to himself and his environment," "a refuge from the trials and irritations of life" $(\mathrm{X})$.

Often this biographical stance is related to the general uncertainties claimed to underlie the Victorian conceptions of liberty and social responsibility, uncertainties due to the rapid industrial and tecnological advances of the century, to the consequent social mobility and instability, to the economic and political theorizations which went under the name of free trade, liberalism and utilitarianism, and to the ensuing ethical debate which characterize 
the period. The ambiguity of Victorian culture and the "plight of the individual faced with either a nameless mass society or an indifferent nature before which he is distinctly alone and 'other"' (Hark 113) is considered to be one of the causes of the popularity of the nonsense genre in the Victorian period. Lear's work is said to reflect this "deep-seated Victorian Angst about the capacity for irrationality and violence in the individual, his society and his universe" (Hark 121). In this uncertain and fluid period, as F. Ferrara notes, we find an unprecedented appearance of literature based both on "good sense" and on nonsense (265).

Nonsense is viewed in this context as a sort of escape genre, an excellent means to elude ambiguous questions, a convenient way to avoid taking a stand. According to Ina Rae Hark, "its nature precludes any clear, unequivocal statement. It is non-sense, admirably suited to areas in which empirical sense proves elusive. Lear creates a multifarious universe which encompasses the pro and contra of many views without relying on the logical consistency that would force value judgments among them" (112-113). However, Lear asserted, at least where the limericks were concerned, that his aim was "nonsense, pure and absolute" for the mere pleasure of "administering innocent mirth to thousands" (Wells XXVI), a viewpoint shared, it seems, by T. S. Eliot, who is reported to have noted in an unpublished lecture given in 1933 at Scripps College, Claremont, that "Lear does not mean to mean anything" (Baker 566).

Does this suggest that a text can be meaningless? Certainly, nonsense seems to break all the rules of semantico-syntactic compatibility, and yet somehow manages to construct discourse. Perhaps, then, an understanding of Edward Lear is best sought in a description of the structural representation of nonsense as genre, and of the verbal strategies specific to the Lear nonsense text. In other words, it may be more justifiable to ask the question: What is the formal apparatus which determines nonsense, that is, which achieves meaning making through rule-breaking? The term nonsense cannot be attached to poems which just relate absurd stories; nor can it be superficially equated with mere parody, unusual rhyming patterns or strange word formations; nor can we be satisfed with trite explanations such as "nonsense verse is simply a type of verse which does not make sense but which raises a smile" (Robbins 568) or, "pure nonsense is entirely dependent on the rejection of what most people consider logical or even normal and an acceptance of the conventions of a completely different universe" (Preminger, Warnke, and Hardeson 572). An explanation of the genre and Lear's contribution to it would require a more linguistically formalized description.

It has been jokingly suggested that "to define true nonsense in the literary sense we can fruitfully adduce related manifestations in the infantile, the senile, the brain-damaged, the drunk-not to mention the senders of telegrams" (Robbins 568). And actually, one can identify in nonsense a whole series of disturbances of linguistic uses present in clinical psychological manuals of speech disorders (Robbins 568). For example,

paraphasia: the use of non-existent words as "borascible" or "splendidopheropherostiphongius."

paragrammatism: grammatical confusions as in "We think so then and"or "We thought so still."

nominal aphasia: the inability to name objects correctly as in "bibbons" for "ribbons." 
jargon aphasia: the use of words unrelated to the topic as in "that oracular Lady of Prague" or " that intrinsic Old Man of Peru."

Broca's aphasia: the misuse, slurring, or mispronunciation of words as in "purpledicular" or " Taky caky," not to mention that beautiful example of stuttering "beeeeeeeestly."

The difference of course is that, whereas in everyday communication, the production of such forms may result in misunderstanding and communication breakdown, the use of such disordered language in nonsense verse produces meaning and satisfaction of message reception. How can this difference be explained? In the words of Stefan Themerson "if the Sense which results from the Versifier's nonsense (VS) differs from the Sense that results from the Logician's nonsense (LS), then what is that amazing quantity X=VS-LS which apparently cannot be obtained by other than nonsensical means?" (5, see also Tigges).

A contribution in this direction has come from studies which have all identified, with varying degrees of explicitness, an order/disorder paradigm for the genre of which the Lear text is exemplary. Among the numerous scholars who have discussed Lear from this point of view, the following should be mentioned. V. Noakes, for example, noting the difficulty in defining the genre, suggests that it is "incongruity of characters, situations or words, plus a predictable stable element such as numbers, choruses, alliteration, or paradoxically, the correct use of words which equals nonsense" (223). C. Izzo, who has produced a very successful Italian translation of Lear, refers to the logic of the incongruous. M. Graffi claims that in the Lear text the two extremes of logic and absurdity are united (115-26). F. Ferrara explains that nonsense uses normal logical schemata but deforms the situation, obtaining a contrast between structural and formal seriousness on the one hand and absurdity of content and incongruity of detail on the other (267). In his admirable study of literary nonsense, W. Tigges notes that one of the most essential characteristics which emerges from the body of research aiming at defining nonsense is that it presents an unresolved tension. According to Tigges, this tension is a balance between presence and absence of meaning (51).

There is a recent noteworthy contribution to an understanding of this concept of nonsense by $\mathrm{T}$. Kemeny, which ap proximates a rather high degree of explicitness in the description of this so-called tension (222). In this study the nonsense utterance is hypothesized to be a linguistic representation of an intermediate structure between the serious utterance on the one hand and the absurd utterance on the other. It is this intermediate status which creates the tension in the text between the tendency toward the construction of discourse and the counter tendency to block integration into a hierarchically superior discourse level. This obstruction is produced, according to Kemeny, by leaving the linguistic constituents in their discrete point form, that is, by means of a strict control of each phoneme, word, concept, event, character of the text. However, although this definition tells us what constitutes nonsense, that is, the production of an utterance at the midway point on the continuum absurd $\rightarrow$ meaningful, the construct which guarantees cohesion of the disparate discrete elements of the nonsense text, and safeguards this balance needs to be clarified further. 
The classic study of E. Sewell suggests that the balance between order and disorder is sustained through play, a concept which has been repeatedly signalled out in the literature on the topic (Tigges). Taking this into consideration, it should be remembered that play is not the anarchic violation of rules, but the construction of a rule breaking system (i.e. the creation of another set of rules) where conditions or restrictions on rules are clearly defined. If we take a look at Lear from this theoretical stance, i.e. if we attempt to define these conditions on rules, we could perhaps draw a clearer picture of how nonsense works in Lear's limericks, poems and songs.

One of the first things we note when we observe the Lear nonsense text is that it abounds in non-words-the various "purpledicular," "borascible," "spongetaneous," which are very similar to the nonsense syllables found in psychological experiments in language processing (Ebbinghaus). A nonsense syllable, as defined in psycholinguistics (Jenkins 459), is characterized by its pronunciability, which is made possible by what is called phonetic distance i.e. the degree to which the novel formation accords with, or departs from, the rule structures of syllable and word formation in a given language. This phonetic distance determines variations in meaningfulness. The nonsense syllable is also influenced by the domain of associations related to the sound. For example, given the utterance [swit], native speakers of English would associate "sweet," "swat," "swish," "switch," "wit," "quit," "sit," "spit," etc. (Jenkins 459), and classify it as "not a word," but "similar to an English word." Therefore these non-words are more than the creation of portmanteau words, "two meanings packed up into one word" to use Humpty Dumpty's definition in Through the Looking Glass. Nor should they be considered neologisms, which are recognized as new words but just the same as words. The Lear formations are word-like non-words, since they activate neither two meanings nor new meanings but several potential meanings, leaving the reader with a sense of ambivalence.

Kemeny notes to this effect that the words invented by Lear are derived from the manipulation of phonemes and from the manipulation of lexemes. He claims that the phonemes are combined on the borderline between sense and noise, while the lexeme is understood as the altered transcription of latent associations (Kemeny 233-34). Perhaps here he refers to formations like "Gromboolian plain," "the Hills of the Chankly Bore," the "Dong" and the "Jumblies."

M. Graffi also emphasizes the importance of association in Lear's use of the geographical term of the limerick. The geographical term is the primary element of Lear's nonsense which sets the tone of what is to follow. It is merely a sound, which embodies the entire first line creating an echoic effect and thereby activating in the reader's mind the most varied associations (121). This can be easily seen in limericks like "There was an old Person of Tring," or "There was an old Man of Kamchatka." In the Lear text which plays heavily with these latent associations, the non-word "spongetaneous" for example probably activates "sponge" and "spontaneous"; the non word "borascible" gi ves rise to associations like "irascible" and "voracious"; for "purpledicular," we would have the associations of "purple" and "perpendicular" etc. What must be emphasized is that these non words are collocated in perfectly acceptable syntactic patterns. The effect on the hearer/reader is recognition of an utterance which I would like to call meaning-bearing but non necessarily the attribution of meaning. In other words the meaning is perceived as 
doubtful. For example, a verse such as "He's a Moppsikon Floppsikon bear" may apparently be almost meaningless as a syntactic string, but can activate in the reader/hearer recognition of similar words in the lexicon (perhaps, "mop" "flop" "floppy" and similarity with the use of the Greek suffix -ikon in English scientific terminology). The reader is left with a suspicion therefore of the possible existence of meaning, a kind of fuzzy image, or feeling of sense. This is how the tension between the two polarities of sense and absurd is constructed. In fact, Bertrand Russell, in discussing what constitutes a "significant sentence," notes that "we are guided by the mere feeling as to what is significant" (3). Similarly, Noam Chomsky, although from a quite different theoretical standpoint, postulates the centrality of the intuition of an ideal speaker/hearer which would guide judgment of utterance acceptability. ${ }^{1}$

Within this manipulation of lexemes there is considerable play given to classical rhetorical figures: alliteration, onomatopeia, etc. However, I would like to emphasize that alliteration in the nonsense of Edward Lear is not the mere repetition of phonemes but rather the repetition of phonologically similar morphemes which are often non-words but word-like. A good example is "winkelty-binkelty tinkled their bell," a phrase composed of two non-words ("winkelty," "binkelty") and three words ("tinkled their bell"). "Winkelty" and "binkelty," though non-words, are a prime example of English word-formation rules and are therefore virtual words, presenting therefore a possible but non-occuring English syntagma. This type of construction, according to a Chomskyan terminology, would be well-formed but meaningless. Yet there is a soupçon of meaning conveyed primarily by the repetition of alliterative-onomatopeic combinations. The whole process seems to be one of morphophonological redundancy, which preserves the little information present in the string and functions therefore as a factor of cohesion between apparently incompatible (basically because non-occurring) elements. Another classic example is "higgledy piggledy hen," where we have the repetition of the sound "iggle" in two multisyllabic non-words ("higgledy," "piggledy"), which is in itself onomatopeic, of course, recalling the cackling of the hen, but which also undergoes semantic re-enforcement, since by latent association (as explained earlier) it activates the word "giggle." Thus, the process of latent association in the Lear nonsense text is all the more effective due to its interaction with the se alliterative and onomatopeic repetitive structures, to a definite effect of redundancy. According to cybernetic theory, redundancy results from the transmission of multiple signals of the code. Its effects are operative especially in discourse which presents a low information load. Communication theory has demonstrated that the scarcer the quantity of information to be transmitted (with respect of course to the maximum hypothetical quantity), the more redundant (i.e. the more repetitive) the message. And of course in traditional rhetoric, redundancy is synonymous with repetition, reiteration and reduplication. It is this redundancy which preserves sense in a semantically precarious string. A verse such as "Fil-jomble, fil-jumble, fil-rumblecome-tumble!" having little semantic information, manages to convey meaning because of the almost obsessive repetition of alliterative-onomatopeic combinations whose sound-sense relationships are never explicit but merely suggested. The reader/hearer is left with an imprecise but definite feeling of sense, with this "fuzzy" image. Another, rather 
extreme, example occurs in the poem Mr. and Mrs. Spikky Sparrow. One of the refrains for instance reads:

\title{
Chippy-wippy sikky tee \\ Bikky-wikky tikkey mee \\ Spikky-chippy wee
}

The stanza is built on the repetition of the minimal pair sounds $/ \mathrm{I} /$ and $/ \mathrm{i}: /$. In this refrain and its variants, the phoneme /I/ is repeated 56 times and the phoneme /i:/ 77 times. Therefore, where you have low information load, meaning is safeguarded by this phonological redundancy, the repetition of discrete phonological units, thereby assuring the necessary text cohesion and consequent text-reader compatibility.

Moreover, this thrust towards the maximum limit of possible word formation, up to the threshold of violation of sense occurs within a rigid syntactico-metrical structure. Lear's limerick, ${ }^{2}$ for example, nearly always begins with the standard formula "There was a young/old man/lady/person of ..." followed by a place-name and occasionally a relative clause, a past tense sentence relating an action and a repetition (refrain-like) of the elements of the first or second line.

\author{
There was a young lady of Lucca \\ Whose lovers completely forsook her; \\ She ran up a tree, \\ And said, "Fiddle-de-dee!" \\ Which embarrassed the people of Lucca.
}

From a metrical point of view, the line is almost always composed of two amphibrachic ${ }^{3}$ trimeters followed by two anapestic dimeters which were at first published as a single tetrameter with internal rhyme and a regular caesura (Byrom 49-50): "She ran up a tree, And said Fiddle-de-dee!" In A Book of Nonsense this limerick pattern is repeated 212 times, and so again on the metrical level we can see how fundamental the concept of redundancy is to the Lear nonsense text.

There is, however, another point that I would like to make in this paper. I would like to call attention to the fact that both redundancy and semantico-syntactic deviancy are constitutive of child language. Redundancy is a child language strategy which compensates for the immature acquisition of rules. Reiteration of a particular linguistic class is functionally explained as the necessity for children to assure that the structure they are trying to generate is fully understood (Menyuk). Deviancy is simply the process by which children gradually reconstruct rules for the speech they hear. Psycholinguists consider the deviancy so common in children's speech to be the manifestation of lexical creativity (Clark). Playing with language structure is the child's way of learning how language works. This would lend support to the hypothesis of the origin of nonsense in the nursery-rhyme tradition of English literature. Nonsense seems to have made its first appearance in the form of entertainment for children, in certain folk tales current in England before the 19th century. Versions of these tales circulated in the form of 
chapbooks of which a famous children's example was entitled The World Turned Upside Down, featuring various nonsensical incidents and words (Carpenter and Prichard 380). C. Bibby notes to this effect that the chapbooks of children's verse appeared when Lear was about 8 to 10 years old and is convinced that "he must have seen them" (47). Let us not forget that the estate of Lear's patron, the Earl of Derby, swarmed with children, with whom (one suspects from Lear's letters and biographies) he was wont to spend a lot of time. Lear could have had then a kind of "caretaker role" in that environment, i.e. he perhaps engaged in the kind of adult-child verbal interaction called "caretaker language" in psycholinguistics, which is characterized by a particular attention and adaptive feedback to child discourse (see Menyuk). V. Noakes notes that "Lear was unusually aware of the sound words make" (224), and what I am adding is that this awareness came also from the children around him, who were, so to speak, his sources. Lear presented many of his nonsense stories and longer poems to the children of friends, and the collection of nonsense limericks The Book of Nonsense carries the explicit dedication: "To the great-grandchildren grand-nephews and grand-nieces of Edward, 13th Earl of Derby." Yet there is still another point which requires reflection. If children enjoy nonsense because it is, so to speak, their language, why has nonsense always been the delight of adults? Byrom notes that by $1870 \mathrm{~A}$ Book of Nonsense had be come one of the favourite pastimes of children and adults alike (151). Since then it has been abundantly published, translated and anthologized and is considered a classic both of children's and adults' literature. We could suggest that adults recognize in nonsense texts their caretaker role. Perhaps, they are simply still attracted to the magical force of child-like word-play, suppressed by the linguistic conventionality of the adult world. F. Ferrara comments that "play is a way of conveying sense to action, a sense which derives from the acceptance of a different (even if absurd) set of rules" (Ferrara 284). We know that if we enter topsyturveydom, we must relinguish our conventional reader-hearer expectations about linguistic compatibilities. We therefore posit a possible world of verbal action and simply wait; i.e. in the terms of R. Barthes, we surrender to the text.

Edward Lear was not only extremely popular with his national Victorian contemporaries but abroad as well, as is testified by his delight during a trip to India to find that Indian children were familiar with "The Owl and the Pussycat" (Carpenter and Richard 307). Since then his work has been translated into numerous languages. In the past ten years, editions of Lear's nonsense have appeared in French, German, Rumanian, Hindi, Bengali, Japanese, Swedish, Armenian, Polish, Arabic and Italian (Index Translatiorum), confirming a prophecy announced by the London journal The Examiner in 1876, which, in referring to the 1871 publication of Nonsense Songs, Stories, Botany and Alphabets, stated: "Nor is it possible to believe that a nonsense poet can ever arise who shall surpass, even if he should equal, these little chef-d'oeuvres" (Carpenter and Prichard 381). This cross-temporal, cross-linguistic and cross-cultural element confirms the point argued in the course of this paper-that the sense of the Lear text is formally inscribed in nonsense as genre, there to be discovered and described, and points moreover to the universal reception of nonsense rules, ${ }^{4}$ that is, rules for breaking rules, and therefore, for making meaning. 


\section{Notes}

1. Chomsky distinguishes here what is grammatical from what is meaningful or significant. $\mathrm{He}$ argues that the examples "Colourless ideas sleep furiously" and "Furiously sleep ideas green colourless" are equally nonsensical. The first example, however, is recognized by the native speaker/hearer of English as grammatical whereas the second would be recognized as ungrammatical (15). For Russell, sentences that are not significant are nonsense. The sentence "The sound of a trombone is blue" is not considered to be nonsense, but merely a false sentence. The sentence "Quadruplicity drinks procrastination" however is cited as an example of nonsense. $\mathrm{S}$. Themerson, himself an author of nonsense stories, noting the example by A. Ingraham, reported in Ogden and Richards, "The gostak distims the doshes," explains that these words, with the exception of the, have no meaning and yet the sentence has meaning since it tells us that something does something to something (1).

2. The origin of the limerick form is to date still unknown. Three possibilities have been credited in literary criticism. In The Oxford Companion to Children's Literature (312), H. Carpenter and M. Prichard note that The Oxford English Dictionary assigns its origin to the custom of singing extemporarized nonsense verses followed by the chorus "Will you come up to Limerick?," an explanation based on an article in Notes and Queries in 1898 in which the term limerick was applied to such verses. C. Bibby, the author of The Art of the Limerick, notes furthermore that the limerick has continued to circulate in clubs, common rooms and sporting fraternities which also explains the ribald nature of many limericks. Related to this oral tradition is the theory that it is originally an Old French form brought to the Irish town of Limerick in 1700 by soldiers returning from the French War (Preminger, Warnke and Hardeson 449). Research in Ireland however has failed to discover any fact which would justify the connection of the limerick with the Irish town of the same name (Carpenter and Prichard 312). C. Bibby comments that "whatever may have been the case in Ireland, there is no doubt about the existence of limericks in Scotland during the eighteenth century and earlier" (55). Another theory, according to Preminger, Warnke and Hardeson (449), seeks its origin in the nursery rhymes published in Mother Goose's Melodies for Children in 1719. At any rate, we are certain of its appearance in a volume entitled The History of Sixteen Wonderful Old Women, published by J. Harris in 1821 and in Anecdotes and Adventures of Fifteen Gentlemen, published by J. Marshall about 1822. In the 1870 edition of More Nonsense Pictures, Rhymes, Botany and alphabets, Lear cited the latter work as the source of his idea (Preminger, Warnke and Hardeson 449). Bibby has also suggested that "we shall eventually discover multiple origins over a long period of time and a wide range of tongues, and that the real problem is that of identifying the factors which led to the limerick's remarkable proliferation in England" (35).

3. The amphibrachic verse is a classical metrical footing consisting of a long syllable preceded and followed by a short one. In English this short-long-short cadence is common in stress groups.

4. On the universality of nonsense in children's literature, see the item "nursery rhymes" in Carpenter and Prichard 382-84.

\section{Works cited}

Baker, William. “T. S. Eliot on Edward Lear: An Unnoted Attribution.” English Studies 6(1983): 564-66.

Barthes, Roland. Le plaisir du texte. Paris: Editions du Seuil, 1973. 
Bibby, Cyril. The Art of the Limerick. London: Research Publishing, 1978.

Byrom, Thomas. Nonsense and Wonder: The Poems and Cartoons of Edward Lear. New York: Dutton, 1977.

Carpenter, Humphrey and Mary Prichard. The Oxford Companion to Children's Literature. Oxford: Oxford University Press, 1984.

Chomsky, Noam. Syntactic Structures. The Hague: Mouton, 1957.

Clark, Eve V. "The Young Word Maker: A Case Study of Innovation in the Child's Lexicon." Language Acquisition: The State of the Art. Eds. E. Wanner and L. Gleitman. Cambridge: Cambridge University Press, 1982.

Ebbinghaus, H. E. Memory: A Contribution to Experimental Psychology. 1885. New York: Dover, 1964.

Ferrara, Fernando. Aspetti e tendenze della poesia vittoriana. Naples: Liguori, 1962.

Graffi, M. "Edward Lear: una logica del nonsense." Il Verri 1 (1973): 115-26.

Hark, Ina Rae. "Eccentricity and the Victorian Angst." Victorian Poetry 16 (1978): 112-22.

Index Translatiorum. Paris: Unesco, 1982.

Izzo, Carlo. Edward Lear: il libro del nonsense. Turin: Einaudi, 1970.

Jenkins, J. "Nonsense Syllables: Comprehending the Almost Incomprehensible Variation." Journal of Experimental Psychology: Learning, Memory and Cognition 11.3: 455-60.

Kemeny, Tomaso. "Il motto di spirito e il nonsense." La comunicazione spiritosa. Ed. Franco Fornari. Florence: Sansoni: 1982.

Lear, Edward. A Book of Nonsense, by Derry Down Derry. London: Thomas McLean, 1846. . A Book of Nonsense. London: Routledge, 1861. Edward Lear's Nonsense Omnibus. 1943. London: Penguin, 1986. Nonsense Songs, Stories, Botany and Alphabets. London: John Bush, 1871. The Complete Nonsense of Edward Lear. Ed. Holbrook Jackson. New York: Dover, 1951.

Menyuk, Paula. Sentences Children Use. Cambridge: MIT Press, 1969.

Noakes, Vivien. Edward Lear: The Life of a Wanderer. London: Collins, 1968.

Ogden and Richards. The Meaning of Meaning. London: n.p., 1945.

Preminger, R., F. Warnke, and B. Hardeson. Encyclopedia of Poetry and Poetics. Princeton: Princeton UP, 1965.

Robbins, R. Rev. of Everyman's Book of Nonsense, by J. Davies. London: Dent, 1981. Times Literary Supplement, 22 May 1981: 568.

Russel, Bertrand. An Inquiry into the Meaning of Truth. London, n.p., 1940.

Sewell, Elizabeth. The Field of Nonsense. London: Chatto and Windus, 1952.

Themerson, Stefan. "On Nonsense and Logic-Fiction." Selected Works. Cracovia: Wydarnictivo Literachie, 1989.

Tigges, Wim. Explorations in the Field of Nonsense. Amsterdam: Rodopi, 1987.

Wells, Carolyn. A Nonsense Anthology. New York: Dover Publications, 1958. 